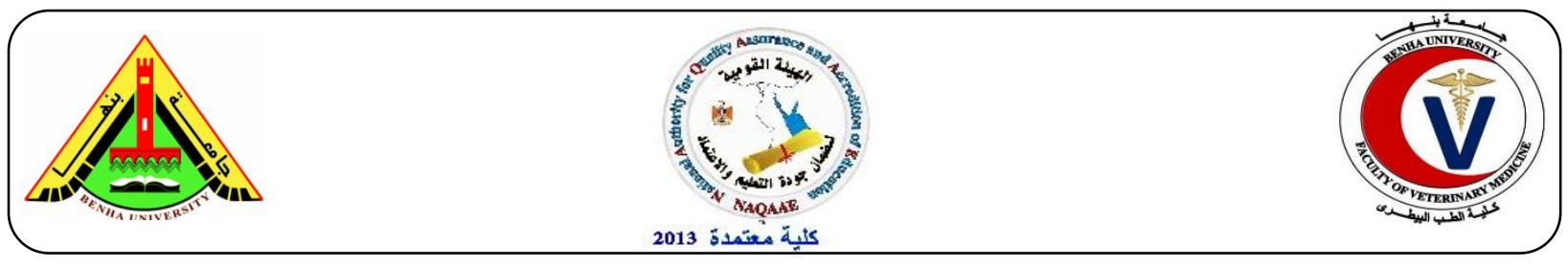

\title{
Clinicopathological changes in calves with respiratory diseases after treatment with essential volatile oil and other drugs
}

\author{
Fararh K.M. ${ }^{1}$, Abd EL-Hamied S.S. ${ }^{2}$, Farid A.S. ${ }^{1}$, El-Sharkawy R.B. ${ }^{2}$ \\ ${ }^{1}$ Clinical Pathology Dep. Fac. Vet.Med. Benha Univ., ${ }^{2}$ Animal Health Research Institute (Zagazig \\ provincial Lab.)
}

\section{A B S T R A C T}

This study was performed on fifteen newly born calves, 3-5-month-old with clinical signs of bronchopneumonia in addition to five clinically healthy calves which considered as control group. After bacterial isolation and identification of the causative microorganisms, fifteen calves from which was found infected with Pasteurella spp. and Haemophilus spp. The diseased calves were divided randomly into three equal groups which respectively, treated with: Gp.1: were treated dose of draxxin $(2.5 \mathrm{mg} / \mathrm{kg}$ body weight) by s/c injection in the neck; Gp.2: were received Draxxin and Meloxicam (single I/M injection of $0.5 \mathrm{mg} / \mathrm{kg}$ b.wt.), while Gp.3: were received draxxin (single s/c injection of $20 \mathrm{mg} / \mathrm{kg} \mathrm{b}$.wt.) +Symopro on drinking water (150-300 ml/1000 L for 5 days). Blood and serum samples were collected from all calves just before treatment, 3 and 10 days post treatment. $\mathrm{pH}, \mathrm{PO} 2$ and $\mathrm{SO} 2$ results recorded significant increase in all treated groups. Meanwhile, $\mathrm{PCO} 2, \mathrm{tCO} 2$ and $\mathrm{HCO} 3$ results showed significant decrease in all treated groups compared with diseased group before treatment. Haptoglobin and fibrinogen results showed significant decrease in all treated groups compared with diseased group before treatment. GSH-PX results revealed significant increase. Meanwhile, MDA results showed significant decrease in all treated groups which comparatively with those before treatment. There was significant increase in cellular immunity (phagocytic index and phagocytic\%) in treated group with draxxin plus sympro when compared with diseased group before treatment.

Keywords: Non-steroidal anti-inflammatory drug, Bovine respiratory diseases, Sympro, Malondialdhyde, Glutathione peroxidase.

\section{INTRODUCTION}

Bovine respiratory disease (BRD) constitutes one of the key health issues and most costly problems occurring in cattle in all part of the world. This disease syndrome was originally termed "shipping fever" since signs often occur shortly after arrival in the feedlot (Urban -Chmiel and Grooms, 2012). About 91 percent of calves diagnosed with BRD were diagnosed within the first 27 days after arrival (Buhman et al., 2000).

Conventional treatment for BRD usually consists of antimicrobial therapy with the application of mucolytics and bronchodilators (Smith, 1996). As the inflammatory response that occurs in BRD forms a significant part of the disease process in the early, and especially chronic, stage, non-steroidal (NSAIDs) antiinflammatory drugs have been recommended ( Lekeux, 1996). 
Clinicopathological changes in calves with respiratory diseases after treatment with essential volatile oil and other drugs

The essential oils can constitute a powerful tool to reduce the development and dissemination of antimicrobial resistance (Toroglu, 2011). In fact, plant essential oils have been used for many years as pharmaceuticals in alternative medicine and as natural therapy (Abd El-Motaal et al., 2008). Eucalyptus essential oil is effective for treatment a number of respiratory problems. This oil is anti-bacterial, antifungal, anti-inflammatory and decongestant which makes it a good ingredient in many medicines for treating respiratory problems (Sadlon and Lamson, 2010).

This study aimed to determine the effect of Meloxicam (NSAID) in a combination therapy with antibiotic (Draxxin), Antibiotic alone or in a combination of essential volatie oil (Symopro) on calves suffering from naturally occurring bronchopneumonia. Blood gases and some inflammatory, antioxidants markers and lastly, cellular immunity was also estimated.

\section{MATERIAL AND METHODS}

\subsection{Experimental Animals:}

Twenty newly born calves, up to 3month-old belonging to a private farm in Sharkia province, from December till February were used in this study. Five of these animals were apparently healthy and free from any internal or external parasites and kept as a control group. The remaining calves were suffering from bronchopneumonia (fever over $40 \circ \mathrm{C}$, cough, nasal discharge from mucous, mucopurulent to purulent, dyspnea and anorexia).The first group were treated with long acting Draxxin; the second group were received Draxxin and Meloxicam (NSAID) while, the third group were received Draxxin and Symopro.

\subsection{Drugs:}

\subsubsection{Draxxin $^{\circledR}$}

Tulathromycin (Pfizer-Company) contain $100 \mathrm{mg} / \mathrm{ml}$ tulathromycin in propylene glycol/water injectable solution ready for use. The recommended dose is a single dose of $2.5 \mathrm{mg} / \mathrm{kg}$ bwt by s/c injection in beef and non-lactating dairy cattle (Skogerboe et al., 2005).

\subsubsection{Meloxicam (Metacam)®}

Solution for injection contains 20 $\mathrm{mg} / \mathrm{ml}$ meloxicam produced by Boehringer IngelheimVetmedica Company, Germany. The recommended therapeutic dose is a single intramuscular injection at a dose of $0.5 \mathrm{mg} / \mathrm{kg}$ of body weight (Friton et al., 2005).

\subsubsection{Symopro ${ }^{\circledR}$}

Essential volatile oil on drinking water bottle contain $150-300 \mathrm{ml} / 1000 \mathrm{~L}$ for 5 consecutive days (Maxima Company). It is a mixture of eucalyptus, lemon oil, cornment oil, rosemary and Echinacea purpurea (Sadlon and Lamson, 2010).

\subsection{Isolation and identification of bacteria:}

Nasal swap samples were collected following the antisepsis procedure to prevent possible bacterial contamination risk and placed in transport mediums (Eurotubo collection swab, Delta lab, Spain).Swab sample were cultured in 5\% sheep blood agar and MacConkey Agar. Plates were inoculated and incubated aerobically and an aerobically at $37^{\circ} \mathrm{C}$ for $24-72$ hours. Bacteria were identified (Ozkanlar et al., 2012). Streptococcus spp. and Staphylococcus spp. growing in the media were examined in terms of colony structure, Gram staining, microscopic appearance.

\subsection{Blood samples:}

Blood samples were collected from the jugular vein of each animal just before treatment, 3 and 10-day post treatment. 
Sample (1) $2 \mathrm{ml}$ of blood was collected in tube containing heparin $(50 \mathrm{i} . \mathrm{u} / \mathrm{ml})$ used for blood gases, plasma fibrinogen estimation and lastly cellular immunity evaluation. Sample (2) was $3 \mathrm{ml}$ of blood taken without anticoagulant collected in a clean and dry tube and left to clot at room temperature for about 2 hours and centrifuged at $3000 \mathrm{rpm}$ for $15 \mathrm{~min}$. Serum samples were drawn in dry clean capped tubes and kept in deep freeze at $-20 \mathrm{oC}$ for Glutathione peroxidase, Malondialdehyde and haptoglobin estimation.

\section{I- Analysis of blood gases:}

Blood gases was determined in whole blood samples by an automated blood gas analyzer using respiratory cassettes (Gastat fax) according to the manufacturer instructions. Right after obtaining the fresh blood samples in a syringe with heparin, the syringe sample were attached to calibrated cassettes into the analyzer.

\section{II-Anti-oxidants concentration:}

Serum concentration of Malondialdehyde was measured according to Satoh (1978).

Serum activity of Glutathione
peroxidase (GSH-PX) was measured
according to Paglia and Valentine (1967).

\section{III- Acute phase proteins:}

Plasma fibrinogen concentrations was measured according to a previously described method (Becker et al., 1984).

Serum haptoglobin was determined photometrically as described by Makimura and Suzuki (1982).

\subsection{Statistical analysis:}

Statistical analysis was performed using the statistical software package SPSS for windows (Version 18.0; SPSS Inc., Chicago, IL). The significance of differences between the experimental groups were evaluated by one-way analysis of variance (ANOVA) (Kinnear and Gray, 2006).

\section{RESULTS}

\subsection{Results of bacteriological examination:}

The bacteriological examination of the cultured swabs from the diseased animals revealed that the isolated bacterial pathogens were Pasteurella spp., Haemophilus spp. and Klebseilla (Table 1).

\subsection{Blood gases results:}

Results of diseased calves showed significant decrease of $\mathrm{pH}, \mathrm{PO} 2$ and $\mathrm{SO} 2$ together with significant increase in $\mathrm{PCO} 2$, $\mathrm{HCO} 3$ and $\mathrm{tCO} 2$ levels. Regarding to blood gases results of the treated groups with draxxin, draxxin plus meloxicam, draxxin plus sympro revealed that $\mathrm{pH}, \mathrm{PO} 2$ and $\mathrm{SO} 2 \%$ were significantly increased, $\mathrm{PCO} 2$ results revealed significant decrease. While, tCO3 and $\mathrm{HCO} 3$ results there were significant decrease at the 3 rd day but $\mathrm{pH}$, $\mathrm{PCO} 2, \mathrm{PO} 2, \mathrm{tCO} 2, \mathrm{HCO} 3$ and $\mathrm{SO} 2 \%$ values recorded significant improvement at 10th day when compared with diseased group before treatment (Tables 3\&4).

\subsection{Acute phase protein and anti-oxidant parameters results:}

Diseased calves suffering from pneumonia revealed significant increase in haptoglobin and fibrinogen. Treated groups with draxxin alone, draxxin plus meloxicam, draxxin plus sympro exhibited significant decrease in haptoglobin and fibrinogen in all treated groups when compared with diseased group before treatment. Concerning to the oxidative status of diseased calves, GSH-PX values recorded significant decrease. Meanwhile, MDA values showed significant increase. Treated groups with draxxin alone, draxxin plus meloxicam, draxxin plus sympro revealed significant increase in 
GSH-PX values and significant decrease in MDA values when compared with diseased group before treatment (Table 5\&6).

\subsection{Immunity results:}

In regard to cellular immunity (phagocytic index and phagocytic \%) of diseased calves revealed significant decrease. Meanwhile, treated groups with draxxin alone, draxxin plus meloxicam, draxxin plus sympro revealed significant increase in both (phagocytic index and phagocytic\%) in comparison with diseased group before treatment (Tables 6\&7).

Table (1): Prevalence of the isolated microorganisms from the nasopharyngeal swabs of the pneumonic cattle-calves: (Total number of the examined animals $=20$ )

\begin{tabular}{cccccccc}
\hline $\begin{array}{c}\text { Isolated } \\
\text { bacteria }\end{array}$ & E.coli & $\begin{array}{c}\text { Pasteurella } \\
\text { spp }\end{array}$ & $\begin{array}{c}\text { Haemophilus } \\
\text { spp. }\end{array}$ & $\begin{array}{c}\text { Staph. } \\
\text { aureus }\end{array}$ & $\begin{array}{c}\text { Strept. } \\
\text { pyogens }\end{array}$ & $\begin{array}{c}\text { Mixed } \\
\text { infection }\end{array}$ & $\begin{array}{c}\text { Total } \\
\text { No. }\end{array}$ \\
\hline $\begin{array}{c}\text { No. of } \\
\text { positive } \\
\text { animals }\end{array}$ & 2 & 8 & 4 & 1 & 1 & 4 & 20 \\
$\%$ & 10 & 40 & 20 & 5 & 5 & 20 & 100 \\
\hline
\end{tabular}

Table (2) Blood gases of healthy and diseased calves before and 3 days post treatment $(n=5)$

\begin{tabular}{|c|c|c|c|c|c|}
\hline \multirow{2}{*}{$\begin{array}{l}\text { Groups } \\
\text { Parameters }\end{array}$} & \multirow{2}{*}{$\begin{array}{c}\text { Healthy } \\
\text { control calves }\end{array}$} & \multirow[b]{2}{*}{$\begin{array}{l}\text { Diseased calves } \\
\text { before treatment }\end{array}$} & \multicolumn{3}{|c|}{ Diseased calves after treatment with } \\
\hline & & & Draxxin & $\begin{array}{c}\text { Draxxin+ } \\
\text { Meloxicam }\end{array}$ & $\begin{array}{l}\text { Draxxin } \\
+ \text { Sympro }\end{array}$ \\
\hline \multirow[b]{2}{*}{$\mathrm{pH}$} & 7.47 & 7.22 & 7.41 & 7.42 & 7.45 \\
\hline & $\pm 0.002^{\mathrm{a}}$ & $\pm 0.004^{\mathrm{d}}$ & $\pm 0.006^{\mathrm{c}}$ & $\pm 0.003^{c}$ & $\pm 0.007^{\mathrm{b}}$ \\
\hline $\mathrm{PCO}_{2}$ & 40.15 & 51.54 & 46.55 & 46.93 & 43.75 \\
\hline$m m h g$ & $\pm 0.61^{\mathrm{d}}$ & $\pm 0.24^{\mathrm{a}}$ & $\pm 0.13^{b}$ & $\pm 0.11^{\mathrm{b}}$ & $\pm 0.25^{\mathrm{c}}$ \\
\hline $\mathrm{PO}_{2}$ & 33.72 & 27.46 & 32.55 & 32.56 & 33.49 \\
\hline$m m h g$ & $\pm 0.008^{\mathrm{a}}$ & $\pm 0.26^{\mathrm{c}}$ & $\pm 0.05^{\mathrm{b}}$ & $\pm 0.04^{\mathrm{b}}$ & $\pm 0.05^{\mathrm{a}}$ \\
\hline $\mathrm{tCo}_{2}$ & 28.58 & 32.38 & 29.90 & 29.30 & 28.71 \\
\hline mmhg & $\pm 0.02^{c}$ & $\pm 0.35^{\mathrm{a}}$ & $\pm 0.18^{b}$ & $\pm 0.32^{b c}$ & $\pm 0.21^{\mathrm{c}}$ \\
\hline $\mathrm{HCO}_{3}$ & 27.27 & 30.80 & 29.36 & 29.25 & 28.13 \\
\hline mmhg & $\pm 0.03^{\mathrm{d}}$ & $\pm 0.24^{\mathrm{a}}$ & $\pm 0.04^{b}$ & $\pm 0.06^{b}$ & $\pm 0.03^{c}$ \\
\hline $\mathrm{SO}_{2}$ & 65.14 & 61.88 & 61.77 & 62.85 & 64.77 \\
\hline$\%$ & $\pm 0.03^{\mathrm{a}}$ & $\pm 0.06^{\mathrm{d}}$ & $\pm 0.12^{\mathrm{d}}$ & $\pm 0.32^{c}$ & $\pm 0.12^{b}$ \\
\hline
\end{tabular}

Results are expressed as mean \pm S.E.M.

Different superscripts $(\mathrm{a}, \mathrm{b}, \mathrm{c})$ within the same rows indicate significant differences at $P \leq 0.05$. 
Table (3): Blood gases of healthy and diseased calves before and 10 days post treatment $(n=5)$

\begin{tabular}{|c|c|c|c|c|c|}
\hline \multirow[b]{2}{*}{ Parameters } & \multirow{2}{*}{$\begin{array}{c}\text { Healthy } \\
\text { control calves }\end{array}$} & \multirow{2}{*}{$\begin{array}{l}\text { Diseased calves } \\
\text { before treatment }\end{array}$} & \multicolumn{3}{|c|}{ Diseased calves after treatment with } \\
\hline & & & Draxxin & $\begin{array}{l}\text { Draxxin+ } \\
\text { Meloxicam }\end{array}$ & $\begin{array}{c}\text { Draxxin } \\
+ \text { Sympro }\end{array}$ \\
\hline $\mathrm{nH}$ & 7.46 & 7.22 & 7.43 & 7.44 & 7.46 \\
\hline $\mathrm{pH}$ & $\pm 0.002^{\mathrm{a}}$ & $\pm 0.004^{c}$ & $\pm 0.005^{b}$ & $\pm 0.006^{\mathrm{b}}$ & $\pm 0.003^{\mathrm{a}}$ \\
\hline $\mathrm{PCO}_{2}$ & 41.17 & 51.54 & 44.55 & 43.83 & 42.07 \\
\hline mmhg & $\pm 0.62^{c}$ & $\pm 0.24^{\mathrm{a}}$ & $\pm 0.13^{b}$ & $\pm 0.50^{\mathrm{b}}$ & $\pm 0.28^{c}$ \\
\hline $\mathrm{PO}_{2}$ & 33.42 & 27.46 & 32.85 & 32.88 & 33.41 \\
\hline$m m h g$ & $\pm 0.004^{\mathrm{a}}$ & $\pm 0.26^{\mathrm{c}}$ & $\pm 0.05^{b}$ & $\pm 0.05^{b}$ & $\pm 0.04^{\mathrm{a}}$ \\
\hline $\mathrm{tCo}_{2}$ & 28.59 & 32.38 & 29.34 & 29.20 & 28.85 \\
\hline mmhg & $\pm 0.02^{c}$ & $\pm 0.35^{\mathrm{a}}$ & $\pm 0.18^{b}$ & $\pm 0.05^{b}$ & $\pm 0.25^{b c}$ \\
\hline $\mathrm{HCO}_{3}$ & 27.28 & 30.80 & 28.35 & 28.56 & 28.21 \\
\hline mmhg & $\pm 0.04^{c}$ & $\pm 0.24^{\mathrm{a}}$ & $\pm 0.04^{\mathrm{b}}$ & $\pm 0.34^{b}$ & $\pm 0.04^{b}$ \\
\hline $\mathrm{SO}_{2}$ & 65.11 & 61.88 & 63.16 & 63.31 & 64.12 \\
\hline$\%$ & $\pm 0.04^{\mathrm{a}}$ & $\pm 0.06^{b}$ & $\pm 0.91^{\mathrm{ab}}$ & $\pm 3.20^{\mathrm{ab}}$ & $\pm 0.13^{a}$ \\
\hline
\end{tabular}

Results are expressed as mean \pm S.E.M.

Different superscripts $(\mathrm{a}, \mathrm{b}, \mathrm{c})$ within the same rows indicate significant differences at $P \leq 0.05$.

Table (4): Inflammatory markers and Oxidative stress of healthy and diseased calves before and 3 days post treatment $(n=5)$

\begin{tabular}{|c|c|c|c|c|c|}
\hline Groups & Healthy & Diseased & \multicolumn{3}{|c|}{ Diseased calves after treatment with } \\
\hline Parameters & $\begin{array}{l}\text { control } \\
\text { calves }\end{array}$ & $\begin{array}{c}\text { calves before } \\
\text { treatment }\end{array}$ & Draxxin & $\begin{array}{l}\text { Draxxin+ } \\
\text { Meloxicam }\end{array}$ & $\begin{array}{r}\text { Draxxin } \\
+ \text { Sympro }\end{array}$ \\
\hline Haptoglobin & 1.20 & 6.30 & 4.60 & 1.80 & 2.4 \\
\hline$m g / d l$ & $\pm 0.02^{\mathrm{e}}$ & $\pm 0.3^{\mathrm{a}}$ & $\pm 0.08^{b}$ & $\pm 0.03^{\mathrm{d}}$ & $\pm 0.05^{\mathrm{c}}$ \\
\hline Fibrinogen & 510.00 & 839.00 & 750.20 & 633.40 & 736.20 \\
\hline$m g / d l$ & $\pm 1.87^{\mathrm{e}}$ & $\pm 4.39^{\mathrm{a}}$ & $\pm 4.03^{b}$ & $\pm 3.20^{\mathrm{d}}$ & $\pm 4.587^{\mathrm{c}}$ \\
\hline GSH-PX & 13.65 & 4.42 & 8.03 & 9.12 & 10.66 \\
\hline$u g / h b$ & $\pm 0.25^{\mathrm{a}}$ & $\pm 0.30^{\mathrm{e}}$ & $\pm 0.14^{\mathrm{d}}$ & $\pm 0.26^{\mathrm{c}}$ & $\pm 0.11^{\mathrm{b}}$ \\
\hline MDA & 29.41 & 41.42 & 39.03 & 35.12 & 30.66 \\
\hline $\mathrm{mmol} / \mathrm{l}$ & $\pm 0.04^{\mathrm{d}}$ & $\pm 0.53^{\mathrm{a}}$ & $\pm 0.47^{\mathrm{b}}$ & $\pm 0.61^{\mathrm{c}}$ & $\pm 1.11^{\mathrm{d}}$ \\
\hline
\end{tabular}

Results are expressed as mean \pm S.E.M.

Different superscripts $(\mathrm{a}, \mathrm{b}, \mathrm{c}, \mathrm{d}, \mathrm{e})$ within the same rows indicate significant differences at $P \leq 0.05$. 
Clinicopathological changes in calves with respiratory diseases after treatment with essential volatile oil and other drugs

Table (5): Inflammatory markers and Oxidative stress of healthy and diseased calves before and 10 days post treatment $(n=5)$

\begin{tabular}{|c|c|c|c|c|c|}
\hline \multirow{2}{*}{$\begin{array}{l}\text { Groups } \\
\text { Parameters }\end{array}$} & \multirow{2}{*}{$\begin{array}{l}\text { Healthy } \\
\text { control } \\
\text { calves }\end{array}$} & \multirow{2}{*}{$\begin{array}{l}\text { Diseased } \\
\text { calves before } \\
\text { treatment }\end{array}$} & \multicolumn{3}{|c|}{ Diseased calves after treatment with } \\
\hline & & & Draxxin & $\begin{array}{c}\text { Draxxin+ } \\
\text { Meloxicam }\end{array}$ & $\begin{array}{l}\text { Draxxin } \\
+ \text { Sympro }\end{array}$ \\
\hline Haptoglobin & 1.10 & 6.3 & 3.4 & 1.4 & 2.2 \\
\hline$m g / d l$ & $\pm 0.03^{\mathrm{e}}$ & $\pm 0.3^{\mathrm{a}}$ & $\pm 0.06^{\mathrm{b}}$ & $\pm 0.02^{\mathrm{d}}$ & $\pm 0.07^{c}$ \\
\hline Fibrinogen & 507.80 & 839.00 & 599.60 & 523.60 & 540.00 \\
\hline$m g / d l$ & $\pm 3.23^{\mathrm{d}}$ & $\pm 4.39^{\mathrm{a}}$ & $\pm 11.66^{b}$ & $\pm 3.14^{\mathrm{cd}}$ & $\pm 5.68^{\mathrm{c}}$ \\
\hline GSH-PX & 13.05 & 4.42 & 8.87 & 10.14 & 11.37 \\
\hline$u g / h b$ & $\pm 0.28^{\mathrm{a}}$ & $\pm 0.3^{\mathrm{e}}$ & $\pm 0.31^{\mathrm{d}}$ & $\pm 0.27^{\mathrm{c}}$ & $\pm 0.23^{b}$ \\
\hline MDA & 29.39 & 41.42 & 36.87 & 31.37 & 30.14 \\
\hline $\mathrm{mmol} / \mathrm{l}$ & $\pm 0.42^{\mathrm{c}}$ & $\pm 0.53^{\mathrm{a}}$ & $\pm 0.42^{\mathrm{b}}$ & $\pm 0.83^{c}$ & $\pm 0.71^{\mathrm{c}}$ \\
\hline
\end{tabular}

Results are expressed as mean \pm S.E.M.

Different superscripts $(\mathrm{a}, \mathrm{b}, \mathrm{c}, \mathrm{d}, \mathrm{e})$ within the same rows indicate significant differences at $P \leq 0.05$.

Table (6): Cellular immunity of healthy and diseased calves before and 3 days post treatment $(\mathrm{n}=5)$

\begin{tabular}{|c|c|c|c|c|c|}
\hline \multirow{2}{*}{$\begin{array}{c}\text { Groups } \\
\text { Parameters }\end{array}$} & \multirow{2}{*}{$\begin{array}{l}\text { Healthy } \\
\text { control } \\
\text { calves }\end{array}$} & \multirow{2}{*}{$\begin{array}{c}\text { Diseased } \\
\text { calves before } \\
\text { treatment }\end{array}$} & \multicolumn{3}{|c|}{ Diseased calves after treatment with } \\
\hline & & & Draxxin & $\begin{array}{c}\text { Draxxin+ } \\
\text { Meloxicam }\end{array}$ & $\begin{array}{l}\text { Draxxin } \\
+ \text { Sympro }\end{array}$ \\
\hline \multirow{2}{*}{ Phagocytic index } & 4.88 & 3.28 & 3.38 & 3.88 & 4.32 \\
\hline & $\pm 0.09^{\mathrm{a}}$ & $\pm 0.07^{\mathrm{d}}$ & $\pm 0.07^{\mathrm{d}}$ & $\pm 0.04^{\mathrm{c}}$ & $\pm 0.09^{b}$ \\
\hline \multirow{2}{*}{ Phagocytic \% } & 74.00 & 58.40 & 59.20 & 67.40 & 69.20 \\
\hline & $\pm 0.32^{\mathrm{a}}$ & $\pm 0.93^{\mathrm{d}}$ & $\pm 0.58^{\mathrm{d}}$ & $\pm 0.51^{\mathrm{c}}$ & $\pm 0.37^{b}$ \\
\hline
\end{tabular}

Results are expressed as mean \pm S.E.M.

Different superscripts $(\mathrm{a}, \mathrm{b}, \mathrm{c}, \mathrm{d}, \mathrm{e})$ within the same rows indicate significant differences at $P \leq 0.05$.

Table (7): Cellular immunity of healthy and diseased calves before and 10 days post treatment $(\mathrm{n}=5)$

\begin{tabular}{|c|c|c|c|c|c|}
\hline \multirow{2}{*}{$\begin{array}{c}\text { Groups } \\
\text { Parameters }\end{array}$} & \multirow{2}{*}{$\begin{array}{l}\text { Healthy } \\
\text { control } \\
\text { calves }\end{array}$} & \multirow{2}{*}{$\begin{array}{c}\text { Diseased } \\
\text { calves before } \\
\text { treatment }\end{array}$} & \multicolumn{3}{|c|}{ Diseased calves after treatment with } \\
\hline & & & Draxxin & $\begin{array}{c}\text { Draxxin+ } \\
\text { Meloxicam }\end{array}$ & $\begin{array}{l}\text { Draxxin } \\
+ \text { Sympro }\end{array}$ \\
\hline \multirow[b]{2}{*}{ Phagocytic index } & 4.88 & 3.28 & 3.38 & 3.88 & 4.32 \\
\hline & $\pm 0.09^{\mathrm{a}}$ & $\pm 0.07^{\mathrm{d}}$ & $\pm 0.07^{\mathrm{d}}$ & $\pm 0.04^{\mathrm{c}}$ & $\pm 0.09^{\mathrm{b}}$ \\
\hline \multirow{2}{*}{ Phagocytic \% } & 74.00 & 58.40 & 59.20 & 67.40 & 69.20 \\
\hline & $\pm 0.32^{\mathrm{a}}$ & $\pm 0.93^{\mathrm{d}}$ & $\pm 0.58^{\mathrm{d}}$ & $\pm 0.51^{\mathrm{c}}$ & $\pm 0.37^{\mathrm{b}}$ \\
\hline
\end{tabular}

Results are expressed as mean \pm S.E.M.

Different superscripts $(\mathrm{a}, \mathrm{b}, \mathrm{c}, \mathrm{d}, \mathrm{e})$ within the same rows indicate significant differences at $P \leq 0.05$. 


\section{DISCUSSION}

The bacteriological examination of the cultured swabs from the diseased animals revealed that the isolated bacterial pathogens were Pasteurella spp., Haemophilus spp. and Klebseilla. These results are in agreement with Saeed and Emad (1990) and Ismail (1991).

Regarding to blood gases blood $\mathrm{pH}$ is a biochemical indicator which must be between narrow intervals (7.2-7.6) for the tissue to perform in the body and affect the body functions negatively and even causes death (Karademir et al., 2001). Results of diseased calves showed significant decrease of $\mathrm{pH}, \quad \mathrm{PO}_{2}$ and $\mathrm{SO}_{2}$ together with significant increase in $\mathrm{PCO}_{2}, \mathrm{HCO}_{3}$ and $\mathrm{tCO}_{2}$ levels these results agree with Cambier et al., (2002) who reported that, blood oxygen levels binding in hypoxic calves $\mathrm{PO}_{2}$ were investigated they showed that diseased animals exhibited a significant acidosis in arterial and venous blood. Also, our results of decrease in $\mathrm{pH}$ supported by (Cambier et al., 2002 and Ok et al., 2005). The lung helps regulate $\mathrm{pH}$ in the body by exhaling carbon dioxide and in severe acidosis, there is rapid respiration in an effort to exhale more $\mathrm{CO}_{2}$ in an effort to correct the imbalance (Montgomery, 2009). In addition, the changes in blood gases were significantly associated with a high respiratory frequency suggesting that the breath rhythm and intensity were insufficient to eliminate $\mathrm{CO}_{2}$ and supply $\mathrm{O}_{2}$. Consequently, a respiratory acidosis has occurred, evidenced throughout a significant decrease in the blood $\mathrm{pH}$ and a significant increase in the circulating proton concentrations. On the contrary, the plasma bicarbonate concentrations were markedly increased in BRD affected calves, confirming the insufficient $\mathrm{CO}_{2}$ elimination (Ozkanlaret al., 2012). Similar results were also reported by Nagyet et al. (2006) who reported marked hypoxemia and hypercapnia were observed in the calves with severe respiratory disease.

Regarding to blood gases results of the treated groups with draxxin, draxxin plus meloxicam, draxxin plus sympro revealed that $\mathrm{pH}$ and $\mathrm{PO}_{2}$ and $\mathrm{SO}_{2} \%$ there were significantly increased. $\mathrm{PCO}_{2}$ results revealed significant decrease. While, $\mathrm{tCO}_{2}$ and $\mathrm{HCO}_{3}$ results showed significant decrease at the $3^{\text {rd }}$ day. $\mathrm{pH}, \mathrm{PCO}_{2}, \mathrm{PO}_{2}$, $\mathrm{tCO}_{2}, \mathrm{HCO}_{3}$ and $\mathrm{SO}_{2} \%$ values recorded significant improvement at $10^{\text {th }}$ day. Our results in group treated with draxxin agree with Tanritanir et al. (2010) who reported that compared to control and diseased calves there were significant increase of $\mathrm{PCO}_{2}$ and $\mathrm{HCO}_{3}$ levels together with significant decrease in $\mathrm{pH}$ and $\mathrm{PO}_{2}$ but one week after treatment with draxxin, $\mathrm{pH}$, $\mathrm{PCO}_{2}$ and $\mathrm{HCO}_{3}$ levels were significantly changed. While, in group treated with draxxin plus meloxicam our findings agree with Lekeux (1996) who reported that acute inflammatory component of pneumonia results in impaired gas exchange and the aim of modulating pulmonary inflammation by the use of NSAIDs are to block the production and/or the effects of inflammatory mediators and modulators which have a deleterious effect on alveolar exchange of gases. But more prominance improvement in group treated with draxxin plus sympro. Similar results obtained by Sadlon and Lamson (2010) who recorded improvement in $\mathrm{PCO}_{2}$ and $\mathrm{SO}_{2}$ due to the effect of sympro in relief effect of colds, influenza, other respiratory infections, rhinitis and sinusitis by decrease airway mucin secretion of tracheal and bronchiole epithelium (Wu, 2016 and Nordqvist, 2017).

Diseased calves suffering from pneumonia revealed significant increase in haptoglobin and fibrinogen. Our results are paralleled to the finding of Angen et al. 
(2009) who reported that the haptoglobin might be the best choice for detecting respiratory diseases under field conditions and to distinguish between calves requiring anti-inflammatory drug.

Treated groups with draxxin alone, draxxin plus meloxicam, draxxin plus sympro exhibited significant decrease in haptoglobin and fibrinogen in all treated groups which were more pronounced decrease in group treated with draxxin plus meloxicam. Similar results agree with Lynch et al. (2010) and Richeson et al. (2013).

Concerning to the oxidative status of diseased calves, GSH-PX values decreased. Meanwhile, MDA values showed significant increase. These results attributed to decreased antioxidant enzyme activity and reduction of blood GSH-PX concentration and these result from a massive and durable production of radical oxygen species during broncho-pneumonia development and lead to exacerbation of oxidative damage in lung (Al-qudah, 2009) . Our results of decrease in GSH-PX in diseased calves with pneumonia agree with (Al-qudah, 2009 and Eleiwa et al., 2014). As it well known that inflammatory diseases are associated with enhanced oxidative reactions and reduce antioxidant defense capabilities (Behiman et al., 2001). These results may be due to the excessive lipid peroxidation in plasma and cells ascribed to many factors or diseases lead to excessive formation of NADPH which in turn promotes lipid peroxidation in the presence of cytochrome P-450 system (Jain, 1989 and Ahmed et al., 2010). Malondialdhyde.MDA is a major and stable end product formed of peroxidation is regarded as a marker of lipid peroxidation (Del et al., 2005).

Treated groups with draxxin, draxxin plus meloxicam revealed that GSH-PX results revealed significant increase in all treated group. Meanwhile, MDA results showed significant decrease in all treated groups when compared to diseased group. This attributed to the anti-inflammatory effects of meloxicam are limited to eicosanoids that act as pro-inflammatory mediators, including thromboxane, prostaglandins and Malondialdhyde (MDA), while activating early immune mediators such as leukotrienes which are responsible for the stimulation of neutrophil function, through the lipooxygenase pathway (Friton et al., 2005). Treated group with draxxin plus sympro revealed that GSH-PX results showed significant increase compared to diseased group. Meanwhile, MDA results showed significant decrease compared to diseased group. Our results supported by Sadlon and Lamson (2010) who explained the role of sympro constituents especially eucalyptus oil which could react biologically as an antioxidant. The free radicals scavenging capability of E.tereticornis oil from fresh and decaying leaves and separate oil constituents potentially leading to oxidative stress (Chirase et al., 2004) could decrease antioxidant capacity and increase lipid peroxidation in the body, thereby increasing susceptibility to disease $(\mathrm{Wu}, 2016$ and Nordqvist , 2017).

Concerning to cellular immunity of the diseased calves phagocytic index and phagocytic percent showed significant decrease. These results agree with Chirase et al., (2004) and Carroll et al., (2007). Also, Sulpizio et al., (2003) who reported that heifers subjected to natural exposure of BRD is often characterized by immunosuppression caused by environmental stressors coupled with a primary viral infection that allows a secondary bacterial infection to establish in the pulmonary tissues. Ttreated groups with draxxin and draxxin plus meloxicam 
compared with diseased group revealed that cellular immunity (phagocytic index and phagocytic \%) recorded significant increase in treated groups with draxxin plus meloxicam. This result similar to Faris et al., (2010) and Eleiwa et al., (2014). Also, treated group with draxxin plus sympro revealed that cellular immunity (phagocytic index and phagocytic \%) recorded significant increase when compared with diseased group. Our results agree with Abd ElMotaal et al., (2008) who explained that, plant essential oils have been used as pharmaceuticals in alternative medicine and as natural therapy and symopro is a natural product based on the essential oils (Eucalyptus, Lemon oil, Cornment oil, Rosemary and Echinacea purpurea) which created especially for dealing with all respiratory symptoms and has a unique expectorant action and has a powerful immune stimulant effect.

It could be concluded that, no adverse reactions related to sympro were reported during the experimental period.Also,use of draxxin plus symprohad a great effect on reduce the respiratory manifestation and correction of blood gases.

\section{REFERENCES}

Abd El-Motaal, A.M., Ahmed, A.M.H., Bahakaim, A.S., Fathi, A. 2008. Productive performance and immunocompetence of commercial laying hens given diets supplemented with eucalyptus. Inter. Journal of Poultry Science, 7 (5): 445-449.

Ahmed, W.M., Ghada, M., El-Khadrawy, N.H.H., Hanafi, E.M., Abd El-Moez, S.I., Amal, R.A. 2010. The relationship between oxidants/antioxidants imbalance and fertility in bufflo-cows. International Journal of Academic Research, 2 (1): 5-9.
Al-qudah 2009. Oxidative stress in calves with acute or chronic bronchopneumonia. Revue. Med. Vet., 160 (5):231-233.

Angen, O., Thomsen, J., Larsen, L.E., Kokotovic, B., Heegaard, P.M., Enemark, J.M. 2009. Respiratory disease in calves: Microbiological investigations on trans-tracheally aspirated broncho alveolar and acute phase protein response. Vet. Microbiol., 28: 137(1-2):165-171.

Buhman, M.J., Perino, L.J., Galyean, M.L., Wittum, T.E., Montgomery, T.H., Swingle R.S. 2000. Association between changes in eating and drinking behaviors and respiratory tract disease in newly arrived calves at a feedlot. Am. J. Vet. Res. 61, 1163-1168.

Becker, U., Bartl, K., Wahlefed, A.W. 1984. A functional photometric assay for plasma fibrinogen. Thromb. Res., 35: 475-484.

Behiman, H.I., Kodman, P.H., Preston, S.I., Gao, S. 2001. Oxidative stress and the ovary. J. Soc. Gynecol. Investigations, 8:540-542.

Buhman, M.J., Perino, L.J., Galyean, M.L., Wittum, T.E., Montgomery, T.H., Swingle, R.S. 2000. Association between changes in eating and drinking behaviors and respiratory tract disease in newly arrived calves at a feedlot. Am. J. Vet. Res., 61: 1163-1168.

Cambier, C., Clerbaux, T., Detry, B., Marville, V., Frans, A., Gustin, P. 2002. Blood oxygen binding in hypoxaemic calves. Vet. Res., 33: 283290.

Carroll, J.A., Forsberg, N.E. 2007. Influence of stress and nutrition on cattle immunity. Vet. Clin. North. Am. Food Anim. Pract., 23: 105-150.

Chirase, N.K., Greene, L.W., Purdy, Ch.W., Loan, R.W., Auvermann, B.W., Parker, D.B., Walborg, E.F., Stevenson, D.E., Xu, Y., Klauning, J.E. 2004. Effect of 
Clinicopathological changes in calves with respiratory diseases after treatment with essential volatile oil and other drugs

transport stress on respiratory disease, serum antioxidant status and serum concentrations of lipid peroxidation biomarkers in beef cattle. American Journal of Veterinary Research, 65: 860-864.

Del, D.R., Stewart, A.J., Pellegrini, N. 2005. A review of recent studies on malondialdehyde as toxic molecule and biological marker of oxidative stress. Nutri. Metab. Cardiovasc. Dis., 15 (4): 316-328.

Eleiwa, N.Z.H., Gad, G.N.A., EL-Shorbagy, A.I.A. 2014. Effect of a combined Oxytetracycline $\mathrm{HCl} /$ Flunixin megluminetherapy on undifferentiated respiratory disease in calves. International Journal of Advanced Research, 2 (3): 387-398.

Faris, A.E.S., Abd EL-Hamied, S.S., Mohamed, M.M., Refaat S.A. 2010. A comparison on the effect of steroidal and non-steroidal anti-inflammatory drugs with antibiotic treatment of respiratory diseases in calves. Suez Canal Veterinary Journal, 1110-6298.

Friton, G.M., Cajal, C., Romero, R.R. 2005. Long-term effects of meloxicam in the treatment of respiratory disease in fattening cattle. Vet. Rec. 156:809-811.

Ismail, M. 1991. Haemophilussomnus as a bacterial cause of pneumonia in buffalo calves in Egypt. Arch Exp. Veterinarmed., 45 (1): 161-164.

Jain, N.C. 1989. Schalm's Veterinary Hematology.4th ed. Lea and Fehiger, Philadelphia,USA.

Karademir, B., Saatc, M., Aksoy, A.R. 2001. The effect of different barn types on blood gases of cattle. Istanbul Univ.Vet.Fak.Derg.,27:385-392.

Kinnear, P., Gray, C. 2006. SPSS 12 made simple. Psychololgy press.

Lekeux, P. 1996. Use of anti-inflammatory drugs in the treatment of bovine respiratory disease complex. In:
Proceedings of the XIX World Buiatric Congress, Edinburgh, pp. 45-49.

Lynch, E.M., Earley, B., McGee, M., Doyle, S. 2010. Effect of abrupt weaning at housing on leukocyte distribution, functional activity of neutrophils, and acute phase protein response of beef calves. BMC Veterinary Research, pneumonia. Journal and veterinary Advances, 8(11):2345-2349.

Makimura, S., Suzuki, N. 1982. Quantitative determination of bovine serum haptoglobin and its elevation in some inflammatory diseases. Jpn. J. Vet. Sci., 44:15-21.

Montgomery, D. 2009. Bovine Respiratory Disease and Diagnostic Veterinary Medicine (Managing Respiratory Diseases in the Herd). University of Nebraska-Lincoln. Animal Science Department. Range Beef Cow Symposium. 280: 1-6.

Nagy, O., Seidel, H., Paulikova, I., Mudron, P., Kovac, G. 2006. Use of blood gases and lactic acid analyses in diagnosis andprognosis of respiratory diseases in calves. Bull. Vet. Inst. Bull. Vet. Inst. Pulawy, 50: 149-152.

Nordqvist, J. 2017. Eucalyptus: what are the health benefits Debra Ros Wilson. Ph.D., MSN, RN, IBCLC, AHN-BC, CHT. Health line UK LTD, Brighton,UK.

Ok, M., Sen, I., Guzelbektas, H., Coskun, A. 2005. The importance of blood gases in the diagnosis of experimentally induced respiratory tract diseases in lambs. Univ.Vet. Bil.Derg.1:119-125.

Ozkanlar, Y., Aktas, M.S., Kaynar, O., Ozkanlar, S., Kirecci, E., Yildiz, L. 2012. Bovine respiratory disease in naturally infected calves: clinical signs, blood gases and cytokine response. Revue Méd.Vét., 163 (3): 123-130.

Paglia, D.E., Valentine, W.N. 1967. Studies on the quantitative and qualitative 
characterization of erythrocyte glutathione peroxidase. J. Lab. Clin. Med., 70:158-169.

Richeson, J.T., Pinedo, P.J., Kegley, E.B., Powell, J.G., Gadberry, M.S., Beck, P.A., Falkenberg, S.M. 2013. Association of hematologic variables and castration status at the time of arrival at a research facility with the risk of bovine respiratory disease in beef calves. JAVMA., 243 (7): 10351041.

Sadlon, A.E., Lamson, D.W. 2010. Immunemodifying and anti-microbial effects of eucalyptus oil and simple inhalation devices. Altern Med. Rev., 15(1):3347.

Saeed, S.S., Emad, M.R. 1990. Incidence and bacterial causes of buffalocalves mortality with respiratory disorder. Vet. Med. J. Giza, 38 (2): $125-138$.

Satoh, K. 1978. Clinical Acta Malondialdehyde , 90: 37.

Skogerboe, T.L., Rooney, K.A., Weigel, D.J., Kilgore W.R. 2005. Comparative efficacy of tulathromycin versus florfenicol and tilmicosin against undifferentiated bovine respiratory disease in feedlot cattle. Vet. There., 6 (2): 180-196.
Smith, R.A. 1996. Therapeutic management of the bovine respiratory disease complex. In: Bovine Respiratory Disease, Schering-Plough Animal Health, pp. 49-56.

Sulpizio, M.J., Drouillard, J.S., Kessen, T.J., Loe, E.R., Montgomery, S.P., Pike, J.N., Sindt, J.J. 2003. Effects of MGA in receiving diets on health, performance, and carcass characteristics. Cattlemen's Day Report of Progress 908. Kansas State Univ. Manhattan.,185-192.

Tanritanir, P., Ragbetli, C., Deger, Y., Ebubekir, C. 2010. Asian Journal of animal and Veterinary Advances, 5(1): 72-76.

Toroglu, S. 2011. In-vitro antimicrobial activity and synergistic/ antagonistic effect of interactions between antibiotics and some spice essential oils. Journal of Environmental Biology, 32(1): 2329.

Urban-Chmiel, R., Grooms, D. L. 2012. Prevention and Control of Bovine Respiratory Disease. Livestock Sci., 3:27-36.

Wu, B. 2016. Can essential oils be used for treating asthma. Debra rose Wilson, Ph.D, msn, rn, ibclc, AHN,CHT. 